総説 第 $29 \cdot 30$ 回教育研修会 $(2008$ 年口腔四学会合同研修会 $)$

「デンタルインプラントの基本とその応用」

\title{
歯周病患者のインプラント治療
}

\author{
辰巳順一
}

\section{Implant treatment for periodontal patients}

\author{
TATSUMI Jun-ichi
}

\begin{abstract}
It is known that the bacterial infection from the periodontal pocket of the adjacent dentition to a periimplant sulcus occurs in a very short term after the implant treatment. Therefore, doing the implant treatment to periodontal patients after periodontal treatment to make the risk of infection by periodontopathic bacteria from teeth a minimum becomes a condition. Moreover, bacterial flora improved by the periodontal treatment once also has the possibility to influence the implant surroundings organization according to the state of the plaque control afterwards. However, there is no scientific index that can judge the quality of the plaque control, and the bacillus in a peri-implant sulcus is encouraged to be inspected regularly. After implant treatment and periodontal treatment, maintenance is necessary for all patients, and to judge the interval of maintenance according to the situation in the mouth. In these days the implant treatment is widely common compared with other odontotherapies. However, a peri-implantitis has occurred in some the cases. The method of treatment to a new disease has not been established yet. A basic clinical consideration in addition will be a pressing need when the future to establish the method of prevention and the treatment method to the peri-implantitis, and it is thought that it is necessary to do the prevention of this disease and standardization of the treatment method.
\end{abstract}

Key words: peri-implantitis (インプラント周囲炎), periodontal patients（柬周疾患患者）, risk factors（リスク因子）, decontamination (除染), periodontopathic bacteria（柬周病原因菌）

は じめ に

㐘科インプラント治療は予知性および永続性が高い治療 法であることが現在では認知されていることから, 欠損補 綴の 1 手段として広く用いられ, 国民の口腔機能の回復に 役立っている. このインプラント治療の成否には術者因子, インプラントシステム因子, 患者因子が影響するといわれ ている，このなかで患者因子については患者の全身疾患， 局所の解剖学的形態, 菊周疾患の有無, 咬合習癖や喫煙習 慣などさまざまな要因があげられる.

特に, 柬周疾患の有無については, 柬周病患者にインプ ラント治療を行う際, 天然柬からの㐘周病原因菌による感 染のリスクを最小限にするための柬周基本治療が終了した のちに行うことが条件となる.これは, 口腔内に存在する 歯周病原因菌がインプラント周囲溝に伝播し, 歯周疾患と

明海大学蒾学部口腔生物再生医工学講座茵周病学分野 Division of Periodontology, Department of Oral Biology and Tissue Engineering, Meikai University School of Dentistry
同様にインプラント周囲粘膜炎やインプラント周囲炎に罹 患する可能性があるからである. 最近の研究結果から，イ ンプラント処置終了後のインプラント周囲粘膜炎の発症率 は平均で $50 \%$, インプラント周囲炎では $28 \%$ とも報告さ れており ${ }^{1)}$, 今後さらに罹患率が上昇することも考えられ る.

\section{歯周病原因菌の感染}

無歯䫈患者へのインプラントを用いた機能回復を行った 場合に, 処置後の細菌叢を調べた結果, 㐘周病原因菌を検 出する頻度は少ないとされている.しかし, 有歯顎患者に おいては失敗した治療例のインプラント周囲細菌叢を調べ た報告で, グラム陰性菌やスピロヘータなどの細菌の比率 が高くなってくるという. 実際にインプラントを用いた機 能回復後, 隣在歯の蒾周ポケットからインプラント周囲溝 への細菌感染は短期間のうちに起きることが知られてい る. Quirynen ら ${ }^{2)}$ はチェッカーボード DNA-DNAハイブ 


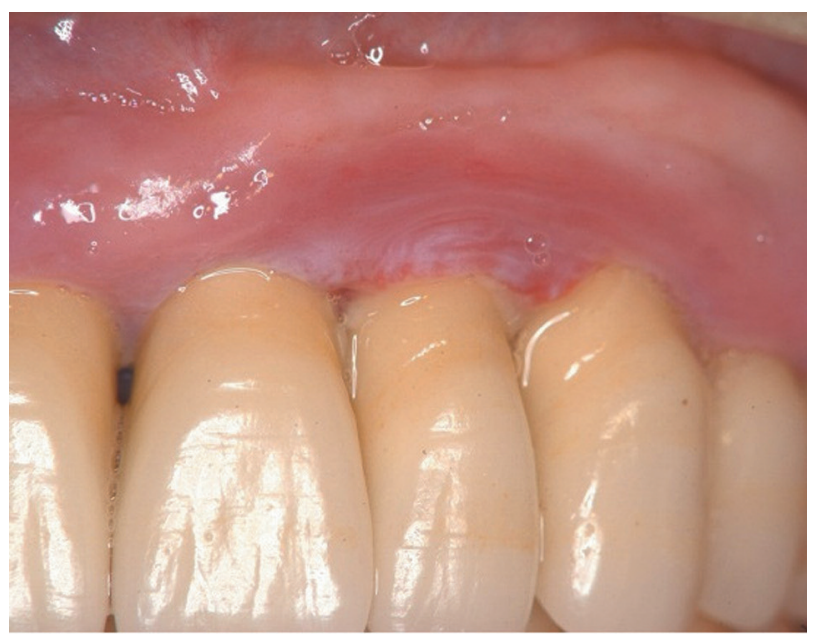

写真 1 初診時のインプラント処置部

リダイゼーション法や培養法を用いてアバットメント連結 後のインプラント周囲溝の細菌の動態を検索したところ, 2 週間以内に数種の柬周病原因菌を含む多くの細菌が確認 されたという。この結果からインプラントの粘膜貫通部が 生じる前にインプラント処置を施す口腔内から柬周病原因 菌を可能な限り減らしておく必要がある.また，一度茵周 治療によって改善した細菌叢, その後のプラークコント ロールの状態によっては影響を及ぼす可能性がある。しか し，プラークコントロールの良否を判定できる科学的な指 標はなく, 定期的にインプラント周囲溝内の細菌検査を行 うことが奨励される。

\section{歯周疾患はインプラントの生存率と 成功率に影響を及ぼすのか?}

インプラントの生存率（survival rate）とは，ある時期の 検査時にインプラントもしくはその修復物が存在するかど うかを意味し，それに比べ，成功率 (success rate) はある 時期の検査時にある一定の条件から外れる合併症が存在し ないかどうかを意味している. Baelum ら ${ }^{3)}$ は 2004 年の報 告で, 歯周治療の経験があるインプラント患者を対象に 14 年間の追跡調査をしたところ, 生存率は歯周疾患罹患経験 があるにもかかわらず高い值を示した，しかし，成功率に ついてはその条件を篇しく（インプラント周囲溝が $4 \mathrm{~mm}$ 以上， bleeding on probing が陽性など）すると，かなり低 い值になることがわかった. また，近年では Klokkevold ら ${ }^{4)}$ が，インプラントの治療成績に柬周疾患，契煙，糖尿病な どがどのように影響するか 1814 編の論文を対象に調査し， システマティック・レビューをした。その結果，歯周治療

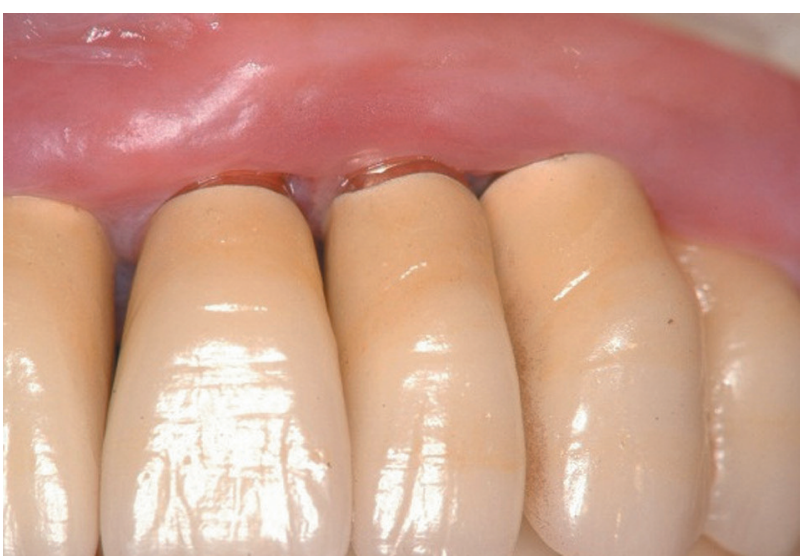

写真 2 初診より 2 か月経過時のインプラント処置部

の既往はインプラント治療の生存率に影響を及ぼさないよ うであった。しかしながら, 歯周治療の既往を有する患者 は, 合併症の頻度が高く, 成功率は低い傾向にあることが 明らかとなった。 以上の結果から, 菊周疾患を有する患者 は，疾患の治療をすればインプラント治療の生存率に影響 を及ぼさないが，成功率には影響を及ぼす可能性があるこ とが分かる.

\section{歯周病の立場からみたインプラント周囲焱の治療法}

インプラント周囲炎を発症した患者の一症例を示す. 患 者はインプラント上部構造装着後, 約 6 か月後からブラッ シング時の出血に気づいていたが放置，その後同部に排膿 や軽い違和感を覚えるようになり，来院した（写真 $\mathbf{1}$ ).

自覚症状があることから患者自身のプラークコントロール は比較的良好であった。診査の結果, 周囲組織の接触痛も 存在していたので，インプラント周囲溝内の洗浄を週 2 回 程度， 2 か月間実施した。その結果，同部の出血排膿はなく なり, 柬肉の発赤もほとんど消失した（写真 2). その後, 全顎的に中程度の柬周疾患を認めたため, 外科的処置を含 む歯周処置を行った，その結果，インプラント周囲溝内の 柬周病原因菌はほとんど検出されなくなり, メインテナン 又時の検査結果も安定した（表 1).このような症例をみて も, 柬周疾患に罹患している患者へのインプラント処置に は事前に菊周治療が必要であると考える.

国民の多くが菊周疾患に罹患していることからも，イン プラント治療を行う症例には的確な歯周治療が必要とされ ると考えられる。 
表1＼cjkstart治療前後のインプラント周囲溝内細菌検査結果

\begin{tabular}{crrr}
\hline & 初診時 & 洗浄後 & 治療1年後 \\
\hline 総菌数 & 160,000 & 41,000 & 1,700 \\
A. aciactinomycetemcomitans & 0 & 0 & 0 \\
$P$. intermedia & 1,000 & 0 & 0 \\
$P$. gingivalis & 11,000 & 83 & 93 \\
B. forsythus & 780 & 0 & 0 \\
\hline
\end{tabular}

\section{インプラント周囲焱の予防}

インプラント周囲炎治療後の長期経過について, Leonhardt $5^{5)}$ が 2003 年に報告している. 彼らは, インプ ラント周囲炎の治療は可能であるが, 彼が報告した時点で は予知性が低く, 用いた除染方法が最良の方法かどうかは 不明であるとしている.しかし，今日では表面処理された インプラント体が多用されており，これに伴いインプラン 卜体表面の形状も非常に複雑化していることから，化学的 な除染が必要であると考えられる. Mombelli らは1992年 に9 名の患者に対し, 機械的デブライトメントおよびクロ ルヘキシジン洗浄後の 1 年間のフォローアップを報告して いる.しかし, 細菌種の検索とそれに対する抗菌薬の選択 的投与は行っていない. Persson ら ${ }^{6)}$ は 2001 年にイヌを 用いた実験で, 同様の実験方法で骨の再生が認められたと している. 5 年後の結果に打いて, P. intermedia, P. nigrescens が検出された患者では, その細菌は周囲㐘周組 織から感染したものと考え, さらに, 本菌の検出されなか った患者では骨吸収はその後認められなかった. 以上の結 果から, 歯周疾患は, 適切な柬周治療をすればインプラン 卜治療の生存率に影響を及ぼさないが, 成功率には影響を 及ぼす可能性があることが分かる.

このような背景からインプラント周囲炎に対しては, 現 在のところ適切な治療法は確立されていないため, インプ ラント処置を行う際には, 可能な限り本疾患を発症させな いような予知性の高い治療を行い, かつ, 適切にメインテ ナンスをするべきであるといえる，そのためには，インプ ラント治療の永続性, 機能性, あるいは審美性を満たすた めにもインプラント周囲のティッシュ・マネージメントは 必要不可欠となる.インプラント埋入の際に考慮すべき八 ードティッシュ・マネージメント（インプラント埋入を目 的とした骨増大) として, (1)骨形態の修正, (2)骨増大, (3)
上顎洞底挙上術などがある. またソフトティッシュ・マネ ージメント（インプラント周囲軟組織の増大や修正）とし て, (1)周囲軟組織量（高さ・幅）の増大, (2)角化組織の獲 得, 増大, (3)小帯や筋の付着異常の修正（口腔前庭拡張） について, 必要に応じ対応する.

特に部分欠損患者に対し, インプラントを含む㐘科治療 を行う場合は, 㐘周治療が不可欠となる.さらに, インプ ラント処置やその他の動的㐘科治療が終了した後も, 患者 の口腔清掃程度や口腔内の状況に応じて, 定期的なメイン テナンスが必要不可欠である.

インプラント治療は他の歯科治療と比較しても成功率や 予知性が非常に高く, 広く普及しつつある治療法であるが, 残念ながらごく一部の症例では治療後, インプラント周囲 炎を発症していることも事実である. 新たな治療方法の開 発にともない生じた, 新たな疾患に対する治療方法は, 未 だ確立されていない. インプラント周囲炎発症に対する予 防方法や治療法を確立するためには，今後さらに基礎的， 臨床的検討が急務であり, 本疾患の予防や治療法のスタン ダリゼーションを行う必要があると考える.

\section{引用 文 献}

1) Zitzmann, N.U. and Berglundh, T.: Definition and prevalence of peri-implant disease. J Clin Periodontol 35: 2862912008.

2) Quirynen, M., Vogels, R., et al.: Dynamics of initial subgingival colonization of 'pristine' peri-implant pockets. Clin Oral Impl Res 17: 25-37 2006.

3) Baelum, V. and Ellegaard, B.: Implant survival in periodontally compromised patients. J Periodontol 75: 140414122004

4) Klokkevold, P.R. and Han, T.J.: How do smoking, diabetes, and periodontitis affect outcomes of implant treatment? Int J Oral Maxillofac Implants 22 (Special Suppl): 173-202 2007.

5) Leonhardt, A., Dahlen, G., et al.: Five-year clinical, microbiological, and radiological outcome following treatment of peri-implantitis in man. J Periodontol 74: 1415-1422 2003.

6) Persson, L.G., Ericsson, I., et al.: Osseointegration following treatment of peri-implantitis and replacement of implant components. An experimental study in the dog. J Clin Periodontol 28: 258-263 2001. 